How to cite this article:

Raja Zainal Hassan, R. R., Hassan, N. A., Sallehuddin, I. S., \& Abdul Aziz, N. N. (2020). Facebook for intercultural communication: The foreign students' experience. Journal of International Studies, 16, 25-37. https://doi.org/10.32890/jis2020.16.2

\title{
Facebook for Intercultural Communication: The Foreign Students' Experience
}

\author{
${ }^{1}$ Raja Rodziah Raja Zainal Hassan, Nor Azlili Hassan, Iza Sharina Sallehuddin \& \\ Nik Norazira Abdul Aziz \\ Faculty of Creative Industries, Universiti Tunku Abdul Rahman \\ Kampar Campus, Perak, Malaysia \\ ${ }^{1}$ Corresponding author: rodziahr@utar.edu.my
}

\begin{abstract}
Computer-mediated communication has been an integral part of how people communicate in today's modern society. The study of the impact of social media on intercultural competency is still in its infancy and has intrigued many scholars and researchers. An integral part of a foreign university student's experience in a host country is to manage cultural differences. Hence, through the use of computer-mediated communication by foreign university students, a better understanding of the impacts of social media (Facebook) on intercultural learning experiences can be achieved. The aims of this study are: 1) to analyse the experience of foreign university students that uses Facebook to communicate with their local peers 2) to examine Facebook usage pattern(s) among foreign university students in Malaysia, and 3) to determine the level of intercultural competency among foreign university students in Malaysia. This study employs the Intercultural Sensitivity Scale (ISS), developed by Chen and Starosta (2000), to analyse the communication patterns of foreign university students in Malaysia that uses Facebook as a platform to learn and cope with cultural differences. This study analysed data from the survey of 210 foreign university students in Klang Valley, Malaysia. The findings from this study suggest that the majority of foreign university students enjoy communicating with their local peers from different cultures by using Facebook. Moreover, the findings indicate that foreign university students are confident when communicating with their local friends, and further concludes that the foreign students are culturally competent. These findings were determined by examining online interactions between foreign students and their local peers, and through Facebook usage patterns obtained from their experience.
\end{abstract}


Raja Rodziah Raja Zainal Hassan, Nor Azlili Hassan,

Iza Sharina Sallehuddin \& Nik Norazira Abdul Aziz

Keywords: Facebook, intercultural competency, intercultural sensitivity scale (ISS), social media, foreign university students.

\section{Introduction}

Globalization and the development of communication technologies have essentially brought together everyone from all walks of life. As a result, cultures and communication have become intertwined and progresses forward concurrently (Seyfi \& Güven, 2016). It is common for individuals to communicate and socialize based on their cultures. Therefore, it is necessary to study the communication behaviours of different cultures to gain a better understanding of intercultural differences (Hall, 1990).

Individuals who live within different cultures have been able to process information that is transferred through various social media. Regardless of cultural gaps and geographical boundaries, social media has the power to connect people around the world. Social media sites, particularly Facebook, has enabled people from every corner of the world to create profiles that highlight their individuality; thus, impacting intercultural learning. The rapid spread and frequent use of Facebook has significantly impacted culture and communication. The famous platform has also influenced the way people live, think and behave, especially for those currently living in different cultural or ethnic groups. The trend of globalization has transformed and changed almost all aspects of human society. These aspects question the idea of a community, redefine cultural identity and civic society, and demand new ways of intercultural communication (Chen \& Zhang, 2000).

Intercultural competence and sensitivity have become an important goal in improving human and ethnic relations, particularly within multicultural societies. Intercultural learning has become an essential goal for successful societal outcomes. The basic aim of intercultural sensitivity studies is a reliable and valid instrument to measure intercultural learning (Coffey, Kamhawi, Fishwick, \& Henderson, 2013). Intercultural sensitivity is an effective facet of intercultural communication competence (Chen \& Starosta, 2000) that motivates people to understand, appreciate and accept different cultures (Chen \& Starosta, 1998). A positive emotional response will encourage more people to respect cultural differences. The quality of intercultural sensitivity includes being effective and interested in other cultures, sensitive towards cultural differences and a willingness to change one's behaviour that adapts to a different culture. These qualities are also indicators of intercultural respect. People with higher intercultural sensitivity exhibit lower ethnocentrism (Dong, Day, \& Collaco, 2008), and are able to deal with intercultural situations than those with lower levels of intercultural sensitivity. Intercultural sensitivity is able to foster respect for cultural differences through intercultural learning, cultivate a multicultural mentality, and prepare people towards a multicultural society.

During intercultural adaptation, people tend to use Facebook as a medium to learn about their host countries, establish and maintain relationships, and to stay informed with events 
in their home countries. Apart from its purpose to connect people, Facebook has changed the way people communicate with everyone and live their daily lives. Through the use of Facebook, its users have the opportunity to communicate and develop intercultural awareness with people of different cultures.

Moreover, the use of Facebook is not limited to networking. Large proportions of Facebook users are university students that actively upload, share and discuss information between their peers to facilitate their academic curriculum. The Internet Users Survey 2017 conducted by Suruhanjaya Komunikasi dan Multimedia Malaysia (SKMM) revealed that students at the tertiary level have the highest percentage $(36.6 \%)$ of internet usage in Malaysia. 97.3\% of Internet users in Malaysia have a Facebook account. Facebook is one of the easiest and fastest method of communication, and has become an important component that encourages intercultural communication (Özdemir, 2017). Hence, the study on foreign university students' experience in Malaysia using Facebook in intercultural communication is timely and relevant as it offers an insight into the ways these experiences could improve intercultural competence.

This study measures intercultural sensitivity gains, based on the online interactions between foreign university students and their local peers through Facebook. This study aims to fill the gap in current literature by providing a better understanding on the ways Facebook influences intercultural sensitivity and learning, and examining the use of Facebook by foreign university students to identify its effects on their intercultural adaptation. This study utilises a quantitative survey method to obtain respondents' feedback on the topic. Specifically, this study focuses on; 1) the foreign university students 'experience using Facebook to connect with their local peers; 2) their Facebook usage pattern(s); and, (3) the students' level of intercultural competency.

\section{Literature Review}

In today's modern world, social media has become an integral part of a student's life. The study conducted by Miller et al. (2016) suggested that social media has encouraged informal and interactive learning among students. This also applies to students studying abroad. The opportunity to study abroad offers students a wide range of experiences that includes the possibility of learning new languages, making new friends and learning about various other cultures around the world (Biagi, Bracci, Filippone, \& Nash, 2012). Foreign university students have used Facebook and other internet technologies to alleviate loneliness and social isolation (Lang, 2012). Apart from that, these students also face challenges in adapting to new cultures within which they live in.

Social media has affected socialization processes (Miller et al., 2016) and enhanced intercultural communicative competence (Clotilde Thomé-Williams, 2016). Foreign students use social media extensively as a virtual platform to improve their intercultural skills (Downey \& Gray, 2012). An important aspect of social media is its effectiveness to 
bridge the gap between individuals that encounter cultural differences, and help promote intercultural communication (Olson \& Kroeger, 2001). Facebook was created to improve face-to-face communication among university students through physical contact and virtual presence (Westlake, 2013).

The movement towards globalization and internationalization has increased the necessity for efficient and productive communication between people from different cultural backgrounds. Hence, intercultural competence is an ongoing process (Biagi et al., 2012). According to Pino and Pino (2017), cultures can be observed through actions (products and practices) and nonverbal cues (perspectives). A study on intercultural competence conducted by Odağ, Wallin, and Kedzior (2016) asserted that students placed more emphasis on their understanding and awareness of other cultures through interaction, communication, and cultural harmony. Personal growth in intercultural competence can be attained through the increased knowledge of the attitudes and skills needed when interacting with other individuals from different cultures (Wickline, 2012).

Intercultural communication competence is comprised of three dimensions: intercultural awareness, intercultural sensitivity and intercultural adroitness (Fritz, Möllenberg, \& Chen, 2002). Intercultural awareness refers to the ability of a person to understand similarities and differences of other cultures, based on the cognitive dimension of intercultural communication competence. Intercultural sensitivity is a factor that relates to a person's emotional ability to appreciate, accept and acknowledge cultural differences. Intercultural adroitness is the behavioral aspect of intercultural communication skills that refers to the ability of a person to meet objectives of communication when communicating with people from other cultures.

\section{Methods}

This study utilized questionnaires for survey-based research to obtain feedback from foreign students living in Malaysia that pertains to the effects of Facebook usage on intercultural learning. Questionnaires were used as it was designed to collect vast quantities of data from various respondents and it is cheaper to distribute (Wilkinson \& Birmingham, 2003). The goal of a survey is to present basic profiling information of the respondents (referred to as demographics) and provide a description on the issues faced under a particular study (Nardi, 2013). Furthermore, it is convenient to employ surveys in sampling as it provides better management of data when there is limited time, resources and workforce (Etikan, Musa, \& Alkassim, 2016). Based on the study conducted by Chen and Starosta (Chen \& Starosta, 2000), the Intercultural Sensitivity Scale (ISS) was selected to examine an individual's assessment (Hammer, Bennett, \& Wiseman, 2003). The scale includes items that refer to environmental stressors of new cultural environments, including communicative processes. ISS was constructed with six main measurements: self-esteem, self-monitoring, openmindedness, empathy, interaction involvement and suspending judgment (Chen \& Starosta, 2000). In addition to these six measurements, Chen and Starosta (Chen \& Starosta, 2000) 
further designed a five-dimensional scale containing the following components: interaction engagement, interaction enjoyment, interaction attentiveness, interaction confidence, and respect for cultural differences. Between January to June 2018, a total of 210 questionnaires were distributed to foreign university students who study in the International Islamic University, Multimedia University, Nottingham University, Taylor's University, Universiti Kebangsaan Malaysia and Universiti Putra Malaysia. Each questionnaire consists of 4 main sections; (1) Demographics, (2) The experience of foreign university students using Facebook in communicating with their local peers and (3) Facebook Usage Pattern(s) and (4) Foreign Students' Level of Intercultural Competency.

\section{Results and Discussions}

The objective of this study is to examine intercultural sensitivity gains within Facebook environments, based on the experiences of foreign university students in Malaysia. It is important to obtain a clear understanding of the experiences of foreign university students that use Facebook to communicate with their local peers, their Facebook usage patterns and the students' level of intercultural competency that could provide valuable information for future studies.

Table 1

Demographic Information of Sample $(N=210)$

\begin{tabular}{llcc}
\hline Items & Information & $\mathbf{n}$ & $\mathbf{\%}$ \\
\hline Gender & Male & 135 & 64.3 \\
& Female & 75 & 35.7 \\
Age & $18-22$ years & 96 & 45.7 \\
& $23-27$ years & 89 & 42.4 \\
& $28-32$ years & 15 & 7.1 \\
\multirow{3}{*}{ Academic Level } & 33 years and above & 10 & 4.8 \\
& Matriculation/Foundation & 10 & 4.8 \\
& Diploma & 11 & 5.2 \\
& Degree & 142 & 67.6 \\
& Master & 37 & 17.6 \\
Continents & PhD & 10 & 4.8 \\
& Asian & 126 & 60 \\
& African & 67 & 31.9 \\
& North America & 6 & 2.85 \\
\hline
\end{tabular}


Raja Rodziah Raja Zainal Hassan, Nor Azlili Hassan,

Iza Sharina Sallehuddin \& Nik Norazira Abdul Aziz

\begin{tabular}{llcc}
\hline Items & Information & $\mathbf{n}$ & $\mathbf{\%}$ \\
\hline & South America & 7 & 3.33 \\
& Europe & 4 & 1.90 \\
Courses & Art and Social Sciences & 108 & 51.9 \\
& Science and Technology & 102 & 48.1 \\
Duration of Stay in & Less than 1 year & 44 & 21.1 \\
Malaysia & & 146 & 69.5 \\
& $1-5$ years & 18 & 8.7 \\
& 6-10 years & 2 & 0.7 \\
\hline
\end{tabular}

From the survey conducted, 210 respondents from different cultural backgrounds had responded to the questionnaires sent for this study. The demographic information of the respondents are presented in Table 1 . About two-thirds of the sample were male $(64.3 \%)$, with the majority of respondents aged between 19 to 27 years old (88.1\%). Out of the 210 foreign university students sampled, 51.9\% were studying arts and social science, and $67.6 \%$ of the respondents are undergraduate students. The time spent by the respondents that have been living in Malaysia ranged between 3 months to 17 years. About $69.5 \%$ of the respondents have been living in Malaysia for a duration of 1 to 5 years. The respondents in this study were mainly from five continents; namely Asia, Africa, North America, South America, and Europe.

The Independent student's T-test statistical analysis was carried out to compare the usage of Facebook in the Malaysian environment and the effects of Facebook usage on foreign university students. Out of the 24 items studied, 7 items corresponded to the respondents' experience, 6 items corresponded to Facebook usage pattern(s) and 11 items corresponded to the foreign university students' level of intercultural competency in Malaysia. The results are recorded in Table 2, 3 and 4.

Table 2

The Foreign University Students' Experience in Communicating with Their Local Peers Using Facebook

\begin{tabular}{|c|c|c|c|c|c|}
\hline & Gender & $\mathbf{N}$ & Disagree (n) & Neutral (n) & Agree (n) \\
\hline \multirow{2}{*}{$\begin{array}{l}\text { Enjoy opportunities to interact } \\
\text { with individuals from different } \\
\text { cultures }\end{array}$} & Male & 135 & $13 \%(17)$ & $25.2 \%(34)$ & $62.2 \%(84)$ \\
\hline & Female & 75 & $13.3 \%(10)$ & $24 \%(18)$ & $62.7 \%(47)$ \\
\hline \multirow{2}{*}{$\begin{array}{l}\text { Pretty sure of myself in } \\
\text { interacting with people from } \\
\text { different cultures }\end{array}$} & Male & 135 & $11.9 \%(16)$ & $26 \%(35)$ & $62.2 \%(84)$ \\
\hline & Female & 75 & $10.7 \%(8)$ & $34.7 \%(26)$ & $54.7 \%(41)$ \\
\hline
\end{tabular}




\begin{tabular}{|c|c|c|c|c|c|}
\hline & Gender & $\mathbf{N}$ & Disagree (n) & Neutral (n) & Agree (n) \\
\hline \multirow{2}{*}{$\begin{array}{l}\text { Find it very hard to chat with } \\
\text { people from different cultures }\end{array}$} & Male & 135 & $53.3 \%(72)$ & $22.2 \%(30)$ & $24.4 \%(33)$ \\
\hline & Female & 75 & $56 \%(42)$ & $18.7 \%(14)$ & $25.3 \%(19)$ \\
\hline \multirow{2}{*}{$\begin{array}{l}\text { Get upset easily when interacting } \\
\text { with people from different } \\
\text { cultures }\end{array}$} & Male & 135 & $65.2 \%(88)$ & $17.8 \%(24)$ & $17 \%(23)$ \\
\hline & Female & 75 & $69.3 \%(52)$ & $16 \%(12)$ & $14.7 \%(11)$ \\
\hline \multirow{2}{*}{$\begin{array}{l}\text { Avoid those situations where } \\
\text { will have to deal with culturally- } \\
\text { distinct persons }\end{array}$} & Male & 135 & $41.5 \%(56)$ & $27.4 \%(37)$ & $31.1 \%(42)$ \\
\hline & Female & 75 & $50.7 \%$ & $22.7 \%(17)$ & $26.7 \%(20)$ \\
\hline \multirow{2}{*}{$\begin{array}{l}\text { Very observant when interacting } \\
\text { with people from different } \\
\text { cultures }\end{array}$} & Male & 135 & $14.8 \%(20)$ & $37 \%(50)$ & $48.1 \%(65)$ \\
\hline & Female & 75 & $21.3 \%(16)$ & $37.3 \%(28)$ & $41.3 \%(31)$ \\
\hline
\end{tabular}

By analyzing the foreign university students' experience using Facebook in Table 2, several statements reflected the positive encounters experienced by foreign university students when communicating with their local peers online. The findings suggest that most respondents $(62.4 \%)$ appreciated the opportunity to interact with other people from different cultures. Moreover, the results are similar to the findings reported by Biagi et al. (2012) and, Chen and Starosta (1998), and further supports the notion that people are happy with the opportunity to interact with other culturally-distinct individuals; and thus, motivate them to improve their language skills and learn about new cultures.

Furthermore, the findings also suggest that intercultural exposure through Facebook usage encourages students to be more observant towards other cultures, and subsequently inculcates cultural sensitivity towards their peers. The majority of respondents $(60 \%)$ agree that they are confident with themselves when interacting on Facebook, and $45.7 \%$ of the respondents feel that they are observant towards different cultures. This finding indicates that individuals develop intercultural sensitivity by being curious of other cultures, recognizes cultural differences and are willing to adapt to ones' culture (Wang \& Zhou, 2016).

According to Liu (2014), positive emotional responses to a different culture would lead to respect for cultural differences. The findings from this study suggest that the majority of respondents $(54.3 \%)$ disagree that it was difficult to communicate with people from different cultures. When asked if they would get upset when interacting with people from different cultures, $66.7 \%$ of the respondents disagreed. Only $29.5 \%$ of the respondents stated that they will avoid situations where they will have to communicate with people who are culturally-distinct on Facebook. The vast majority of the foreign university students took the opportunity to communicate with their local peers through Facebook.

The results from Table 3 provide valuable insights into the patterns of Facebook usage among the majority of foreign university students when learning about other cultures. Facebook became an important medium that enabled these students to communicate openly with their 
Raja Rodziah Raja Zainal Hassan, Nor Azlili Hassan,

Iza Sharina Sallehuddin \& Nik Norazira Abdul Aziz

culturally-distinct peers. The Internet and social media have progressively expanded the domain of communication, beyond the immediate cultural and geographic borders (Liu, 2014). This was evident from the findings, where $63.3 \%$ of the respondents used Facebook to obtain as much information from their peers of different cultural backgrounds.

Table 3

Facebook Usage Pattern(s) among Foreign University Students in Intercultural Communication

\begin{tabular}{|c|c|c|c|c|c|}
\hline & Gender & $\mathbf{N}$ & Disagree (n) & Neutral (n) & Agree (n) \\
\hline $\begin{array}{l}\text { Sociable when interacting } \\
\text { with people from different } \\
\text { cultures on Facebook }\end{array}$ & $\begin{array}{l}\text { Male } \\
\text { Female }\end{array}$ & $\begin{array}{c}135 \\
75\end{array}$ & $\begin{array}{l}7.4 \%(10) \\
6.7 \%(5)\end{array}$ & $\begin{array}{l}17 \%(23) \\
18.7 \% 14)\end{array}$ & $\begin{array}{l}75.6 \%(102) \\
74.7 \%(56)\end{array}$ \\
\hline $\begin{array}{l}\text { Tend to wait before forming } \\
\text { impression of culturally- } \\
\text { distinct counterparts on } \\
\text { Facebook }\end{array}$ & $\begin{array}{l}\text { Male } \\
\text { Female }\end{array}$ & $\begin{array}{c}135 \\
75\end{array}$ & $\begin{array}{c}12.6 \%(17) \\
12 \%(9)\end{array}$ & $\begin{array}{l}45.2 \%(61) \\
46.7 \%(35)\end{array}$ & $\begin{array}{l}42.2 \%(57) \\
41.3 \%(31)\end{array}$ \\
\hline $\begin{array}{l}\text { Try to obtain as much } \\
\text { info when interacting } \\
\text { with people from different } \\
\text { cultures on Facebook }\end{array}$ & $\begin{array}{l}\text { Male } \\
\text { Female }\end{array}$ & $\begin{array}{c}135 \\
75\end{array}$ & $\begin{array}{c}11.8 \%(16) \\
12 \%(9)\end{array}$ & $\begin{array}{l}25.9 \%(32) \\
28 \%(21)\end{array}$ & $\begin{array}{l}64.6 \%(87) \\
61.3 \%(46)\end{array}$ \\
\hline $\begin{array}{l}\text { Sensitive to culturally- } \\
\text { distinct counterpart's subtle } \\
\text { meanings during chatting } \\
\text { on Facebook }\end{array}$ & $\begin{array}{l}\text { Male } \\
\text { Female }\end{array}$ & $\begin{array}{c}135 \\
75\end{array}$ & $\begin{array}{l}32.5 \%(44) \\
29.3 \%(22)\end{array}$ & $\begin{array}{l}28 \%(38) \\
34.6 \%(26)\end{array}$ & $\begin{array}{l}39.2 \%(53) \\
36 \%(27)\end{array}$ \\
\hline $\begin{array}{l}\text { Often give positive } \\
\text { responses to culturally- } \\
\text { distinct counterpart during } \\
\text { online interaction }\end{array}$ & $\begin{array}{l}\text { Male } \\
\text { Female }\end{array}$ & $\begin{array}{c}135 \\
75\end{array}$ & $\begin{array}{l}11.1 \%(15) \\
9.3 \%(7)\end{array}$ & $\begin{array}{l}25.9 \%(35) \\
28 \%(21)\end{array}$ & $\begin{array}{l}62.9 \%(85) \\
62.6 \%(47)\end{array}$ \\
\hline $\begin{array}{l}\text { Often show understanding } \\
\text { to counterparts by using } \\
\text { Facebook features }\end{array}$ & $\begin{array}{l}\text { Male } \\
\text { Female }\end{array}$ & $\begin{array}{c}135 \\
75\end{array}$ & $\begin{array}{l}14 \%(19) \\
14.7 \%(11)\end{array}$ & $\begin{array}{l}20 \%(27) \\
33.3 \%(25)\end{array}$ & $\begin{array}{l}65.9 \%(89) \\
52 \%(39)\end{array}$ \\
\hline
\end{tabular}

Based on the findings of Facebook usage patterns, the students were keen to communicate with their culturally-distinct peers online. According to Portalla and Chen (2010), intercultural communication competence can be defined as an individual's ability to achieve their communication goals, while effectively and appropriately utilizing communication behaviours, such as possessing behavioural flexibilities to observe an interaction, distinguishing and making use of the appropriate behaviours, and adapting to the specific situational context when negotiating between different individuals that are present within a culturally diverse environment. The majority of respondents (75.2\%) from the six universities were sociable when interacting with people of different cultures on Facebook. The results show that $62.9 \%$ of the respondents often gave positive responses to culturally- 
distinct individuals, while $61 \%$ of the respondents indicated that they used features existing on Facebook to express their understanding or reaction towards their peers.

According to Biagi et al. (2012), the ability to recognize, analyse and reflect upon cultural differences and similarities will lead to a more profound knowledge of one's own culture. This knowledge will essentially become a tool for communication with other cultures and for the experiences encountered abroad. The findings from this study highlight the positive attitude among respondents towards cultural differences based on their experience of living in Malaysia. Additionally, $42 \%$ of the respondents tended to wait before forming an impression, while $38.1 \%$ of the respondents felt that they were sensitive to subtle meanings when interacting with people from different cultures.

Table 4

Foreign University Students 'Level of Intercultural Competency in Malaysia

\begin{tabular}{|c|c|c|c|c|c|}
\hline & Gender & $\mathbf{N}$ & Disagree (n) & Neutral (n) & Agree (n) \\
\hline $\begin{array}{l}\text { I am open-minded to people } \\
\text { from different cultures. }\end{array}$ & $\begin{array}{l}\text { Male } \\
\text { Female }\end{array}$ & $\begin{array}{c}135 \\
75\end{array}$ & $\begin{array}{l}7.4 \%(10) \\
1.3 \%(1)\end{array}$ & $\begin{array}{l}3.7 \%(5) \\
4 \%(3)\end{array}$ & $\begin{array}{l}88.9 \%(120) \\
94.7 \%(71)\end{array}$ \\
\hline $\begin{array}{l}\text { I always know what to say } \\
\text { when interacting with people } \\
\text { from different cultures. }\end{array}$ & $\begin{array}{c}\text { Male } \\
\text { Female }\end{array}$ & $\begin{array}{c}135 \\
75\end{array}$ & $\begin{array}{l}11.1 \%(15) \\
10.7 \%(8)\end{array}$ & $\begin{array}{c}26.7 \%(36) \\
44 \%(33)\end{array}$ & $\begin{array}{l}62.2 \%(84) \\
45.3 \%(34)\end{array}$ \\
\hline $\begin{array}{l}\text { I would not accept the } \\
\text { opinions of people from } \\
\text { different cultures. }\end{array}$ & $\begin{array}{c}\text { Male } \\
\text { Female }\end{array}$ & $\begin{array}{c}135 \\
75\end{array}$ & $\begin{array}{l}72.6 \%(98) \\
81.3 \%(61)\end{array}$ & $\begin{array}{l}9.6 \%(13) \\
16 \%(12)\end{array}$ & $\begin{array}{c}17.8 \%(24) \\
2.7 \%(2)\end{array}$ \\
\hline $\begin{array}{l}\text { I feel confident when } \\
\text { interacting with people from } \\
\text { different cultures. }\end{array}$ & $\begin{array}{c}\text { Male } \\
\text { Female }\end{array}$ & $\begin{array}{c}135 \\
75\end{array}$ & $\begin{array}{c}8.9 \%(12) \\
4 \%(3)\end{array}$ & $\begin{array}{l}14.8 \%(20) \\
21.3 \%(16)\end{array}$ & $\begin{array}{c}76.3 \%(103) \\
74.7 \%(56)\end{array}$ \\
\hline $\begin{array}{l}\text { I respect the ways people } \\
\text { from different cultures } \\
\text { behave. }\end{array}$ & $\begin{array}{c}\text { Male } \\
\text { Female }\end{array}$ & $\begin{array}{c}135 \\
75\end{array}$ & $\begin{array}{c}5.9 \%(8) \\
4 \%(3)\end{array}$ & $\begin{array}{l}10.4 \%(14) \\
21.3 \%(16)\end{array}$ & $\begin{array}{c}83.7 \%(113) \\
74.7 \%(56)\end{array}$ \\
\hline $\begin{array}{l}\text { I respect the values of } \\
\text { people from different } \\
\text { cultures. }\end{array}$ & $\begin{array}{c}\text { Male } \\
\text { Female }\end{array}$ & $\begin{array}{c}135 \\
75\end{array}$ & $\begin{array}{l}5.9 \%(8) \\
5.3 \%(4)\end{array}$ & $\begin{array}{c}11.9 \%(16) \\
0 \%(0)\end{array}$ & $\begin{array}{c}82.2 \%(111) \\
94.7 \%(71)\end{array}$ \\
\hline
\end{tabular}

The findings on the level of competency among foreign students in Malaysia from Table 4 reveal that most males and females were able to adapt to people from different cultures. The majority of the respondents (91\%) felt that they were open-minded when accepting a culture other than their own. This supports the results that most respondents $(75.7 \%)$ disagree that they do not accept views from people who are from different cultures. The majority of respondents $(86.7 \%)$ felt that they respected the values and principles brought on by other cultures. This was reflected in the current findings, where approximately $80.5 \%$ of the respondents respected the behavior of others that are from different cultures. The 
results also suggested that more than half of the respondents (56.2\%) felt that they were able to interact with people from different cultures. Moreover, about $75.7 \%$ of the respondents felt that they have high levels of confidence when interacting with people from different cultures.

Most of the respondents have stayed in Malaysia between 1 to 5 years. The majority of foreign students sampled in the study live outside the university campus. However, they have made efforts to befriend the people around them including the local community. This is in line with the study conducted by G. Maharaja (2018), and suggests that students studying overseas would develop intercultural competence and individual progression, which was in line with the findings obtained from the respondent's account of their daily life with the local community. Additionally, they were able to learn about Malaysians and were aware of the topics discussed within the Malaysian culture (Wickline, 2012). This positive impact on the students had created significant improvements in problem-solving, and individual and social intercultural competence (Dwyer, 2004). The findings also revealed that these students were comfortable to approach other people who are ethnically or culturally different. Hence, the foreign students exhibited characteristics of globally competent citizens that are capable of interacting with people of different cultures throughout their lifetime with a higher level of awareness and sensitivity (Biagi et al., 2012). According to Sawyer and Guo-Ming Chen (2012), Facebook enhances social lives by eliminating the element of distance. The social media platform brings together individuals of diverse backgrounds and encourages communication between them. Henceforth, due to the exposure to different cultures through online platforms, these foreign university students were prepared to overcome the challenges when confronting Malaysians from different ethnic and cultural backgrounds.

\section{Conclusion}

In summary, this study examined the experience of foreign university students in Malaysia that uses Facebook to communicate with their local peers, their Facebook usage patterns and their level of intercultural competency. The findings from this study highlighted the experience, trends and intercultural competency that the majority of foreign university students have gained by using Facebook to communicate with their local peers of different cultures. Facebook is undeniably an impactful platform that can influence the way people think and behave in a multicultural society. Moreover, the results highlight the majority of respondents that have positively embraced the opportunities to interact with people from different cultures.

Furthermore, the notion of being a foreigner was not an issue for the respondents when communicating with other people and learning about their cultures. The findings further revealed that intercultural exposure through Facebook encouraged the students to become more observant and culturally sensitive towards their peers from different cultures. The patterns of Facebook usage among the majority of foreign university students have 
shown to be effective in learning about other cultures, where the respondents were keen to communicate with their culturally-distinct peers online. Moreover, the foreign students were found to be open-minded in accepting different cultures. This essentially pointed to positive cultural competency. Most of the respondents respected the values and behaviour of other people who were from different cultures. Their positive response created a united community among foreign and local students.

In a nutshell, the findings helped create a better understanding on the issues that promoted intercultural communication among foreign university students. It is imperative to obtain more practical proof of the elements of intercultural communication that affects the acceptance of different cultures through the advancement of technology, amidst increasing racism throughout the world. This study is useful for future research on intercultural communication in Malaysia. Subsequently, policymakers and governments should play a critical role in the education and training of its culturally diverse society. Training through universal education courses, and lifetime learning will offer essential information and communication technology abilities that would enable communities to develop intercultural communication. Further investigation is necessary to identify the levels of intercultural communication competency among foreigners in Malaysia. Additionally, other segments of the population should also be examined to provide better understanding on the subject matter.

\section{Acknowledgment}

We gratefully thank Universiti Tunku Abdul Rahman for the financial support we receive for this research.

\section{References}

Biagi, F., Bracci, L., Filippone, A., \& Nash, E. J. (2012). Instilling reflective intercultural competence in education abroad experiences in Italy: The FICCS Approach + Reflective Education, 89(1), 21-33.

Chen, G.-M., \& Starosta, W. J. (1998). Foundations of intercultural communication. Boston: MA: Allyn \& Bacon.

Chen, G.-M., \& Starosta, W. J. (2000). The development and validation of the intercultural sensitivity scale. Seattle.

Chen, G.-M., \& Zhang, K. (2000). New media and cultural identity in the global society. In Handbook of research on discourse behaviour and digital communication: Language structures and social interaction. Hershey, PA: Idea Group Inc.

Clotilde Thomé-Williams, A. (2016). Developing Intercultural communicative competence in portuguese through skype and facebook. Intercultural Communication Studies, 1, 213-233. Retrieved from http://web.uri.edu/iaics/files/XXV1-Ana-Clotilde-ThoméWILLIAMS.pdf 
Coffey, A. J., Kamhawi, R., Fishwick, P., \& Henderson, J. (2013). New media environments' comparative effects upon intercultural sensitivity: A five-dimensional analysis. International Journal of Intercultural Relations, 37(5), 605-627.

Dong, Q., Day, K. D., \& Collaco, C. (2008). Overcoming ethnocentrism through developing intercultural communication sensitivity and multiculturalism. Human Communication, 11(1), 27-38.

Downey, G., \& Gray, T. (2012). Blogging with the Facebook generation: Studying abroad with Gen Y. Australian Association for Research in Education and Asia-Pacific Educational Research Association Conference, 1-12. Retrieved from http://eric. ed.gov/?id=ED542292

Dwyer, M. M. (2004). More is better: The impact of study abroad program duration. Frontiers: The Interdisciplinary Journal of Study Abroad, 10, 151-164.

Etikan, I., Musa, S. A., \& Alkassim, R. S. (2016). Comparison of convenience sampling and purposive sampling. American Journal of Theoretical and Applied Statistics, 5(1), $1-4$.

Fritz, W., Möllenberg, A., \& Chen, G.-M. (2002). Measuring intercultural sensitivity in different cultural contexts. Intercultural Communication Studies, 11(2), 165-176.

Hall, E. T. (1990). The silent language. New York: Anchor Books.

Hammer, M. R., Bennett, M. J., \& Wiseman, R. (2003). Measuring Intercultural Sensitivity: The Intercultural Development Inventory. International Journal of Intercultural Relation, 27(4), 421-443.

Lang, A. (2012). Exploring the potential of social network sites in relation to intercultural communication. Arts \& Humanities in Higher Education, 11(1/2), 120-139. https:// doi.org/10.1177/1474022210394141

Liu, S. (2014). Becoming intercultural: Exposure to foreign cultures and intercultural competence. China Media Research, 10(3), 7-14.

Maharaja, G. (2018). The Impact of study abroad on college students' intercultural competence and personal development. International Research and Review: Journal of Phi Beta Delta, 7(2).

Miller, D., Costa, E., Haynes, N., Mcdonald, T., Sinanan, J., Spyer, J., ... Wang, X. (2016). Education and young people. In How the World Changed Social Media Book (pp. 70-84). Retrieved from http://www.jstor.org/stable/j.ctt1g69z35.12

Nardi, P. M. (2013). Doing survey research. A guide to quantitative methods (3rd ed.). London: Paradigm Publishers.

Odağ, Ö., Wallin, H. R., \& Kedzior, K. K. (2016). Definition of intercultural competence according to undergraduate students at an International University in Germany. Journal of Studies in International Education, 20(2), 118-139. https://doi. org/10.1177/1028315315587105

Olson, C. L., \& Kroeger, K. R. (2001). Global competency and intercultural sensitivity, 5(2), 116-137.

Özdemir, E. (2017). Promoting EFL learners' intercultural communication effectiveness: A focus on Facebook. Computer Assisted Language Learning, 30(6), 510-528. https:// doi.org/10.1080/09588221.2017.1325907 
Pino, B. G. (2017). The cross-cultural awareness of pre-service spanish teachers author ( $s$ ): Barbara González Pino and Frank Pino. Published by : American Association of Teachers of Spanish and Portuguese Stable. Retrieved from http://www.jstor.org/ stable/40648361 REFERENCES. Linked $r$, 92(2), 303-308.

Portalla, T., \& Chen, G.-M. (2010). The development and validation of the intercultural effectiveness scale. Intercultural Communication Studies, 19(3), 21-37.

Sawyer, R., \& Guo-Ming Chen. (2012). The impact of social media on intercultural adaptation. Intercultural Communication Studies, 21(2).

Seyfi, M., \& Güven, D. (2016). Influence of new media on intercultural communication: An example of an erasmus student. Informacijos Mokslai, 74, 24-37.

Wang, W., \& Zhou, M. (2016). Validation of the short form of the intercultural sensitivity scale (ISS-15). International Journal of Intercultural Relations, 55, 1-7.

Westlake, E. J. (2013). Friend me if you Facebook. TDR: The Drama Review, 52(4), 21-40. https://doi.org/10.1162/dram.2008.52.4.21

Wickline, V. B. (2012). The crossing borders program: Increasing intercultural competency via structured social interactions. Psychology Learning and Teaching, 11(3), 374381. https://doi.org/10.2304/plat.2012.11.3.374

Wilkinson, D., \& Birmingham, P. (2003). Using research instruments: A guide for researchers. New York: Routledge Falmer. 